\title{
Aporphine Alkaloids as Ligands for Serotonin Receptors
}

\section{Nirav Kapadia ${ }^{1,2^{*}}$ and Wayne Harding ${ }^{1,2}$}

${ }^{1}$ Department of Chemistry, Hunter College, City University of New York, 695 Park Ave, New York, NY 10065, USA

${ }^{2}$ Chemistry Program, Graduate Center, City University of New York, 365 Fifth Ave, New York, NY 10035, USA

\begin{abstract}
The aporphine alkaloids are known to have affinities as the dopaminergic, adrenergic and serotonergic receptor system. Hence the aporphine template can be considered as a privileged scaffold for the design of selective monopotent as well as multi-potent Central Nervous System (CNS) ligands. This review attempts to summarize the recent Structure Activity Relationship (SAR) studies of aporphine alkaloids specifically at the serotonin receptor system. Based on the obtained SAR information it can be concluded that aporphines have great potential to be developed as potent serotonergic ligands.
\end{abstract}

Keywords: Aporphine; Central nervous system; Ligands; Alkaloids

\section{Introduction}

Aporphine alkaloids are natural and synthetic alkaloids that possess a tetracyclic framework. Chemically they incorporate a tetrahydroisoquinoline substructure and belong to the isoquinoline class of alkaloids. More than 500 members of this class of alkaloids have been isolated. Aporphine alkaloids are widely distributed in Annonaceae, Lauraceae, Monimiaceae, Menispermaceae, Hernandiaceae and other plant families [1] (Figure 1).

Both naturally occurring and synthetic aporphine alkaloids possess diverse range of pharmacological actions. Figure 1 shows the basic aporphine skeleton [2].

\section{Pharmacological Effects of Aporphine Alkaloids}

Aporphine alkaloids exhibit a plethora of effects within the Central Nervous System (CNS). There are a number of aporphine alkaloids reported as ligands at dopamine and serotonin receptors $[1,3]$. Ligands at the $\mathrm{D}_{1}$ and $\mathrm{D}_{2}$ dopamine receptor subtypes have a potential role in the treatment of Parkinson's disease, schizophrenia, Attention Deficit Hyperactivity Disorder (ADHD), depression, and drug abuse [4-6]. In fact, $(R)$ - Apomorphine (2) which is considered to be a prototype of aporphine alkaloids by many, has been approved for the treatment of advanced stages of Parkinson's disorder [7]. Ligands at the $5-\mathrm{HT}$ serotonin receptor subtype have been useful in the treatment of anxiety, schizophrenia and depression [8-11] (Figure 2).

Aporphines are also ligands at the $5-\mathrm{HT}_{2 \mathrm{~A}}$ and $5-\mathrm{HT}_{7}$ receptors. Selective $5-\mathrm{HT}_{2 \mathrm{~A}}$ ligands have promising applications in the treatment of drug abuse and insomnia. Mixed dopamine/5- $\mathrm{HT}_{2 \mathrm{~A}}$ ligands have potential for the alleviation of symptoms of depression and schizophrenia $[12,13]$. Ligands at the $5-\mathrm{HT}_{7}$ receptor have shown promising results for the treatment of sleep disorders, migraine and depression [14-16]. Moreover aporphines possessing affinity at the dopamine and serotonin receptors have potential use as PET<smiles>c1ccc2c(c1)CC1NCCc3cccc-2c31</smiles>

Figure 1: Basic aporphine skeleton<smiles>CN1CCc2cccc3c2[C@H]1Cc1ccc(O)c(O)c1-3</smiles>

Figure 2: $(R)$ - Apomorphine

(Positron Emission Tomography) and SPECT (Single Photon Emission Computed Tomography) radiotracers for brain imaging studies [17]. Aporphines are also reported as inhibitors of the enzyme Acetylcholinesterase and as antagonists of the $\alpha_{1}$-adrenergic receptor and thus have potential therapeutic role in the treatment of Alzheimer's disease and hypertension respectively [18-21].

Thus the aporphine scaffold can be considered a privileged scaffold for the design of CNS ligands. A majority of the work in the early 1990s has focused on the design of aporphine alkaloids as ligands for the dopamine receptor system. In terms of the serotonin receptors, aporphines have mostly been studied as ligands at the $5-\mathrm{HT}_{1 \mathrm{~A}}$ receptor. Some of this previous work has been nicely summarized in previously published reviews $[1,3]$.

\section{Aporphine as 5-HT ${ }_{1 \mathrm{~A}}$ Ligands}

The first aporphine alkaloid reported as a selective serotonin ligand was reported by Canon and co- workers in 1988 [22]. The $(R)-(-)-$ 10-Methyl-11-hydroxyaporphine $(R-3)$ (Figure 3) was originally designed as a dopamine receptor ligand. Surprisingly $R-3$ displayed serotonergic agonistic activity with a high degree of selectivity for the 5-HT receptor. Further studies revealed that the $S$ isomer of 3 $(S-3)$ was an antagonist at the $5-\mathrm{HT}_{1 \mathrm{~A}}$ receptor [23]. This trend of enantiomers having opposing pharmacological effects was found to be consistent with other aporphine enantiomers displaying opposing effects at the dopaminergic receptors (Figure 3 ).

*Corresponding author: Nirav Kapadia, Department of Chemistry, Hunter 772-5330; E-mail: nrkkapadia@gmail.com

Received March 26, 2016; Accepted April 12, 2016; Published April 18, 2016

Citation: Kapadia N, Harding W (2016) Aporphine Alkaloids as Ligands for Serotonin Receptors. Med chem (Los Angeles) 6: 241-249 doi:10.4172/21610444.1000353

Copyright: (c) 2016 Kapadia N, et al. This is an open-access article distributed under the terms of the Creative Commons Attribution License, which permits unrestricted use, distribution, and reproduction in any medium, provided the original author and source are credited. 
In order to probe the role of the $\mathrm{C}-10$ methyl group compound 4 that lacked a C-10 methyl group was evaluated for dopaminergic and serotonergic activity. Both the enantiomers of compound $\mathbf{4}$ were found to possess dopaminergic activity but lacked any appreciable serotonin $5-\mathrm{HT}_{1 \mathrm{~A}}$ activity [24]. This clearly indicated a significant role of the $\mathrm{C}-10$ methyl group towards the enhanced 5- $\mathrm{HT}_{1 \mathrm{~A}}$ affinity of $\mathbf{3}$ (Figure $4)$.

It was further shown that both the C-10 methyl and C-11 hydroxyl group in compound 3 are required for affinity at the 5-HT receptor. This was evident from the observed lower affinity of the mono methylated compound 5 [25]. Furthermore, the high affinity at the $5-\mathrm{HT}_{1 \mathrm{~A}}$ receptor of compound 3 is unique and specific to an 11-hydroxy, 10-methyl substitution pattern. Having this substitution at other positions (such as in compounds 6 and 7) resulted in complete loss of affinity at the $5-\mathrm{HT}_{1 \mathrm{~A}}$ receptor [26]. High affinity for the 5- $\mathrm{HT}_{1 \mathrm{~A}}$ receptor was also observed in the case of compound $\mathbf{8}$, which possesses a similar ortho hydroxyl/hydroxyl methyl substitution [27] (Figure 5).

Based on molecular docking studies, the C-11 hydroxyl group makes a hydrogen bond interaction with Ser198 and Ser193 residues of the $5-\mathrm{HT}_{1 \mathrm{~A}}$ and $\mathrm{D}_{2}$ receptors respectively. The main difference however is the interaction of the $\mathrm{C}-10$ methyl group wherein it interacts with a lipophilic pocket in the $5-\mathrm{HT}_{1 \mathrm{~A}}$ receptor, which is not available in the case of the $\mathrm{D}_{2}$ receptor. The absence of a similar lipophilic pocket around the $\mathrm{C}-10$ methyl group in the $\mathrm{D}_{2}$ receptor explained the high selectivity of 3 for the $5-\mathrm{HT}_{1 \mathrm{~A}}$ receptor over the $\mathrm{D}_{2}$ receptor [28].

The existence of this lipophilic pocket was further tested by Hedberg<smiles>Cc1ccc2c(c1O)-c1cccc3c1[C@@H](C2)N(C)CC3</smiles>

$R-3$<smiles>Cc1ccc2c(c1O)-c1cccc3c1[C@@H](C2)N(C)CC3</smiles>

$S-3$
Figure 3: Structure of $R$ and $S$ enantiomers of compound $\mathbf{3}$.<smiles>CN1CCc2cccc3c2[C@H]1Cc1cccc(O)c1-3</smiles>

$R-4$<smiles>CN1CCc2cccc3c2[C@H]1Cc1cccc(O)c1-3</smiles>

$S-4$
Figure 4: Structure of $R$ and $S$ enantiomers of compound 4.

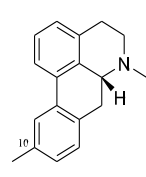

$R-5$

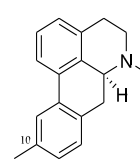

$S-5$

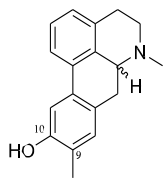

6

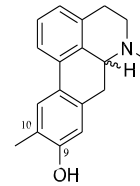

7

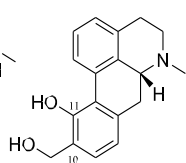

$R-8$
Figure 5: Structure of $R$ and $S$ enantiomers of compounds 5, positional isomers $\mathbf{6}$ and $\mathbf{7}$ and compound 8 . and co-workers by the evaluation of a series of $\mathrm{C}-10$ substituted aporphine compounds [29]. Substitution of bulky groups at the C-10 position (compound 9, 10, 11 and 12) resulted in dramatic loss of affinity for the 5-HT ${ }_{1 \mathrm{~A}}$ receptor whereas small alkyl group substituents (compound 13) were well tolerated, thus confirming the existence of the lipophilic "methyl" pocket, which is able to accommodate only small groups.

In contrast to the previously observed strict requirement of a C-11 hydroxyl/C-10 methyl substitution, a series of mono C-11 substituted aporphine compounds $(14,15$ and 16) were found to have good affinity as well as selectivity for the 5- $\mathrm{HT}_{1 \mathrm{~A}}$ receptors [29]. Based on molecular modeling studies substituents at the $\mathrm{C}-11$ position interacted in a manner that was different from the previously seen hydrogen bond interaction of the $\mathrm{C}-11$ hydroxyl group with the $5-\mathrm{HT}_{1 \mathrm{~A}}$ receptor. In the case of C-11 substituents, significant interactions were seen with a pocket lined by Ser168, Met172, Thr196. Ser199, Thr200, Phe362, Ala365 and Leu366. This indicated that the proposed methyl pocket was much larger, and suitable C-11 substituents could interact with it. This hypothesis of a larger lipophilic pocket was further confirmed by Zhang et al. by the synthesis and evaluation of compounds 17, 18 and 19 that lacked a C-11 hydroxyl group yet displayed high affinity at the $5-\mathrm{HT}_{1 \mathrm{~A}}$ receptor [30].

Other reported SAR studies include the evaluation of C10 substituted long chain carbamate (20 and 21 ) or amide (22 and 23) aporphines [31]. These compounds displayed only moderate affinity at the 5-HT receptor as shown in Table 1 . Similarly limited studies have been done at other positions of the aporphine scaffold with regards to the 5-HT 1 affinity. Zhang and co-workers reported the evaluation of C-2 substituted aporphine compounds $(\mathbf{2 4}, 25$ and 26) which did not show any appreciable affinity at the $5-\mathrm{HT}_{1 \mathrm{~A}}$ receptor, although the number of compounds studies are too less to make a general conclusion [32] (Figure 6).

Although an $\mathrm{N}$-methyl group is not absolutely required for $5-\mathrm{HT}_{1 \mathrm{~A}}$ affinity as indicated by compounds $\mathbf{2 7}$ and $\mathbf{2 8}$, an increase in affinity and selectivity for the 5-HT $\mathrm{HA}_{1 \mathrm{~A}}$ receptor was observed when the size of the substituent was decreased to a methyl or a hydrogen group (Table 1).

\section{Aporphines as 5- $\mathrm{HT}_{2 \mathrm{~A}}$ Ligands}

Majority of the work of aporphine alkaloids as ligands at the $5-\mathrm{HT}_{2 \mathrm{~A}}$ receptor has mainly focused on the natural alkaloid nantenine. Nantenine (29) was isolated from the fruit of Nandina domestica Thunberg [33]. Indra and co-workers in 2002 showed that nantenine inhibited 5-hydroxy-L-tryptophan (l-5-HTP) induced head-twitch response by blocking $5-\mathrm{HT}_{2 \mathrm{~A}}$ receptors in mice [34]. Later the same group reported SAR studies showing nantenine as an antagonist at the $5-\mathrm{HT}_{2 \mathrm{~A}}$ and $\alpha_{1}$ receptors $[35,36]$. Studies done by Fantegrossi revealed the ability of nantenine to block and reverse MDMA induced physiological effects such as hyperthermia, locomotor stimulation and head-twitch responses in mice. These anti-MDMA effects of nantenine were attributed to its antagonism at the $5-\mathrm{HT}_{2 \mathrm{~A}}$ and $\alpha_{1}$ receptors [37] (Figure 7).

Research in our group has focused on the synthesis and evaluation of nantenine analogues as $5-\mathrm{HT}_{2 \mathrm{~A}}$ antagonists. The first accomplished step in this direction was to synthesize racemic nantenine and screen it across available CNS receptors via the Psychoactive Drug Screening Program (PDSP) of the NIH. Results from this screening showed that nantenine is highly selective for the $\alpha_{1 \mathrm{~A}}$ receptor $\left(\mathrm{K}_{\mathrm{i}}=2 \mathrm{nM}\right)$ compared to other $\alpha_{1 \mathrm{~A}}$ subtypes. At the $5-\mathrm{HT}_{2 \mathrm{~A}}{ }_{\mathrm{A}}$ receptor, nantenine was found to have moderate affinity $\left(\mathrm{K}_{\mathrm{i}}=850 \mathrm{nM}\right)$ [38]. In order to improve the potency and selectivity of nantenine analogues for the $5-\mathrm{HT}_{2 \mathrm{~A}}$ receptor, 


\begin{tabular}{|c|c|c|c|c|c|c|c|c|}
\hline \multirow[t]{2}{*}{ Compound } & \multirow[t]{2}{*}{$\mathbf{R}_{1}$} & \multirow[t]{2}{*}{$\mathbf{R}_{2}$} & \multirow[t]{2}{*}{$\mathbf{R}_{3}$} & \multirow[t]{2}{*}{$\mathbf{R}_{4}$} & \multicolumn{3}{|c|}{$K_{i}(n M)$} & \multirow[t]{2}{*}{ Ref. } \\
\hline & & & & & $5-\mathrm{HT}_{1 \mathrm{~A}}$ & $D_{1}$ & $\mathrm{D}_{2}$ & \\
\hline$R-3$ & $\mathrm{OH}$ & $\mathrm{Me}$ & $\mathrm{H}$ & $\mathrm{Me}$ & 0.45 & 382 & 1070 & {$[22,29]$} \\
\hline$S-3$ & $\mathrm{OH}$ & $\mathrm{Me}$ & $\mathrm{H}$ & $\mathrm{Me}$ & 39 & - & - & [23] \\
\hline$R-4$ & $\mathrm{OH}$ & $\mathrm{H}$ & $\mathrm{H}$ & $\mathrm{Me}$ & 296 & 236 & 41.90 & {$[24,29]$} \\
\hline$S-4$ & $\mathrm{OH}$ & $\mathrm{H}$ & $\mathrm{H}$ & $\mathrm{Me}$ & - & - & - & [24] \\
\hline$R-5$ & $\mathrm{H}$ & $\mathrm{Me}$ & $\mathrm{H}$ & $\mathrm{Me}$ & $1.20^{\mathrm{a}}$ & - & - & [25] \\
\hline$S-5$ & $\mathrm{H}$ & $\mathrm{Me}$ & $\mathrm{H}$ & $\mathrm{Me}$ & $6.80^{a}$ & - & - & [25] \\
\hline 6 & $\mathrm{H}$ & $\mathrm{OH}$ & $\mathrm{Me}$ & $\mathrm{Me}$ & - & - & - & [26] \\
\hline 7 & $\mathrm{H}$ & $\mathrm{Me}$ & $\mathrm{OH}$ & $\mathrm{Me}$ & - & - & - & [26] \\
\hline 8 & $\mathrm{OH}$ & $\mathrm{CH} 2 \mathrm{OH}$ & $\mathrm{H}$ & $\mathrm{Me}$ & 2.4 & 1390 & 7000 & [27] \\
\hline 9 & $\mathrm{OH}$ & $\mathrm{Ph}$ & $\mathrm{H}$ & $\mathrm{Me}$ & 1090 & 9400 & $>1000$ & [29] \\
\hline 10 & $\mathrm{OMe}$ & 2-furyl & $\mathrm{H}$ & $\mathrm{Me}$ & 995 & 14000 & 582 & [29] \\
\hline 11 & $\mathrm{OH}$ & $\mathrm{COMe}$ & $\mathrm{H}$ & $\mathrm{Me}$ & 1720 & 4620 & 2760 & [29] \\
\hline 12 & $\mathrm{OMe}$ & $\mathrm{CH}=\mathrm{CH}_{2}$ & $\mathrm{H}$ & $\mathrm{Me}$ & 108 & 1440 & 1750 & [29] \\
\hline 13 & $\mathrm{OH}$ & $\mathrm{Et}$ & $\mathrm{H}$ & $\mathrm{H}$ & 9.20 & 782 & 2050 & [29] \\
\hline 14 & $\mathrm{Ph}$ & $\mathrm{H}$ & $\mathrm{H}$ & $\mathrm{Me}$ & 1.80 & 3630 & 233 & [29] \\
\hline 15 & 2-OMe-Ph & $\mathrm{H}$ & $\mathrm{H}$ & $\mathrm{Me}$ & 26.90 & $>3000$ & 1330 & [29] \\
\hline 16 & 2-OH-Ph & $\mathrm{H}$ & $\mathrm{H}$ & $\mathrm{Me}$ & 28.50 & 3750 & 1570 & [29] \\
\hline 17 & $\mathrm{OCH}_{2} \mathrm{CCH}$ & $\mathrm{H}$ & $\mathrm{H}$ & $\mathrm{Pr}$ & 55 & - & - & [30] \\
\hline 18 & O-Allyl & $\mathrm{H}$ & $\mathrm{H}$ & $\mathrm{Me}$ & 12 & - & - & [30] \\
\hline 19 & $\mathrm{OCH} 2 \mathrm{CCH}$ & $\mathrm{H}$ & $\mathrm{H}$ & $\mathrm{Me}$ & 14 & - & - & [30] \\
\hline 20 & NHCOOEt & $\mathrm{H}$ & $\mathrm{H}$ & $\mathrm{Pr}$ & 94 & $54.6^{b}$ & $44.3^{b}$ & [31] \\
\hline 21 & $\mathrm{NHCOOBu}$ & $\mathrm{H}$ & $\mathrm{H}$ & $\mathrm{Pr}$ & 96 & $70.2^{b}$ & 871 & [31] \\
\hline 22 & $\mathrm{NH}_{2}$ & $\mathrm{H}$ & $\mathrm{H}$ & $\mathrm{Pr}$ & 276 & $57.1^{b}$ & 352 & [31] \\
\hline 23 & $\mathrm{NHCOPr}$ & $\mathrm{H}$ & $\mathrm{H}$ & $\mathrm{Pr}$ & 380 & 16.1 & 13.5 & [31] \\
\hline 27 & $\mathrm{OH}$ & $\mathrm{Me}$ & $\mathrm{H}$ & $\mathrm{H}$ & 3.20 & 23800 & $>10000$ & [29] \\
\hline 28 & $\mathrm{OH}$ & $\mathrm{Me}$ & $\mathrm{H}$ & $\mathrm{Pr}$ & 12.30 & $>2000$ & 249 & [29] \\
\hline
\end{tabular}

${ }_{b}^{\mathrm{a}} \mathrm{D} 50$ values $(\mu \mathrm{M})$

$\%$ inhibition values

Table 1: Affinity values of aporphine derivatives at the $5-\mathrm{HT}_{1 \mathrm{~A}}$ receptor.<smiles>CCCCC(=O)Oc1cccc2c1-c1cc(OC)cc3c1[C@H](C2)N(C)CC3</smiles>

24<smiles>COc1cc2c3c(c1)-c1cccc(N)c1CN(C)C3C2</smiles>

25<smiles>CN1CCc2cc(N)cc3c2C1Cc1cccc(N)c1-3</smiles>

26
Figure 6: Structure of compounds 24,25 and 26 .

a systematic SAR study was initiated. A brief discussion of our previous findings is described.

At the $\mathrm{C} 1$ position several linear and branched alkyl substitutions were evaluated $[39,40]$. Table 2 shows the binding affinity $(K)$ values for a series of $\mathrm{Cl}$ substituted nantenine analogues. Progressive increase in the alkyl chain length at this position, resulted in increased affinity at the $5-\mathrm{HT}_{2}$ receptor. More importantly the affinity of these compounds at the $\alpha_{1 \mathrm{~A}}$ receptor was completely abolished, thus suggesting that the $\mathrm{C} 1$ position could play a vital role in fine tuning<smiles>COc1cc2c3c(c1OC)-c1cc4c(cc1C[C@H]3N(C)CC2)OCO4</smiles>

Figure 7: Structure of $( \pm)$-nantenine.

the selectivity of nantenine. As seen in Table 2, the $\mathrm{C} 1$ ethyl analogue $(30, \mathrm{~K}=890 \mathrm{nM})$ was found equipotent to nantenine. Substitution with propyl (31, $\mathrm{K}=297 \mathrm{nM})$ and butyl $(32, \mathrm{~K}=274 \mathrm{nM})$ groups resulted in three times increase in potency. The $n$-hexyloxy analogue $\left(34, \mathrm{~K}_{\mathrm{e}}=71\right.$ $\mathrm{nM}$ ) which was the most potent compound identified in this series, was 11 times more potent than nantenine at the $5-\mathrm{HT}_{2 \mathrm{~A}}$ receptor. 


\begin{tabular}{|c|c|c|c|c|}
\hline \multirow[t]{2}{*}{ Compound } & \multirow[t]{2}{*}{$\mathbf{R}_{1}$} & \multicolumn{2}{|c|}{$K_{e}(n M)^{a}$} & \multirow[t]{2}{*}{ Ref. } \\
\hline & & $5-\mathrm{HT}_{2 \mathrm{~A}}$ & $\alpha_{1 \mathrm{~A}}$ & \\
\hline (士)- 29 & $\mathrm{Me}$ & 850 & 36 & [39] \\
\hline 30 & Et & 890 & - & [39] \\
\hline 31 & $n-\mathrm{Pr}$ & 297 & - & [39] \\
\hline 32 & $n$-Bu & 274 & - & [39] \\
\hline 33 & $n$-Pen & 171 & - & [39] \\
\hline 34 & $n$-hex & 71 & $>10000$ & [40] \\
\hline 35 & CyclopropylMe & 68 & $>10000$ & [40] \\
\hline 36 & CyclobutylMe & ND & $>10000$ & [40] \\
\hline 37 & CyclopentylMe & ND & $>10000$ & [40] \\
\hline 38 & CyclohexylMe & 1722 & $>10000$ & [40] \\
\hline 39 & Isobut & 367 & $>10000$ & [40] \\
\hline 40 & Isopen & ND & $>10000$ & [40] \\
\hline 41 & 2-EthylBu & 806 & $>10000$ & [40] \\
\hline 42 & allyl & 70 & $>10000$ & [40] \\
\hline 43 & $\mathrm{CH}_{2} \mathrm{CN}$ & $>10000$ & 711 & [41] \\
\hline 44 & $\mathrm{CH}_{2} \mathrm{CH}=\mathrm{CHCH}_{3}(E)$ & 723 & 1980 & [41] \\
\hline 45 & $\mathrm{CH}_{2} \mathrm{CH}=\mathrm{C}\left(\mathrm{CH}_{3}\right)_{2}(E)$ & 2074 & $>10000$ & [41] \\
\hline 46 & $\mathrm{CH}_{2} \mathrm{C}_{6} \mathrm{H}_{4}-p-\mathrm{Br}$ & 9.2 & $>10000$ & [41] \\
\hline
\end{tabular}

aND=Not determined

Table 2: Binding affinity data of $\mathrm{C}-1$ nantenine analogues.

Compound 35 which can be considered as branched analogue of the $n$-butyl analogue also displayed significant improved affinity (35, $\mathrm{K}=68 \mathrm{nM}$ ). However an increase in the size of the ring (from 3 membered up to 6 membered) resulted in either compounds having weak agonist activity (36 and 37 ) or compounds having complete loss of affinity (38). Alternatively compound 39 which is an open chain analogue of the cyclopropyl analogue methyl analogue resulted in a 5 fold drop in affinity. Similarly homologation of $\mathbf{3 9}$ to compounds $\mathbf{4 0}$ and 41 produced compounds having reduced affinity for the 5- $\mathrm{HT}_{2 \mathrm{~A}}$ affinity.

Incorporation of an allyl group at the $\mathrm{C} 1$ position resulted in comparable activity to the cyclopropylmethyl analogue. This can be attributed to the electronic similarity between the allyl and the cyclopropylmethyl group. $\left(42, \mathrm{~K}_{\mathrm{e}}=70 \mathrm{nM}\right)$. In a more recent study, we explored several other allylic groups at the $\mathrm{C} 1$ position [41]. Overall from this study it was concluded that branched allylic substituents (compounds $\mathbf{4 4}$ and $\mathbf{4 5}$ ) as well as other allylic isosteric replacements (compound 43) were not tolerated for affinity at the $5-\mathrm{HT}_{2 \mathrm{~A}}$ receptor. Compound 46 that has a $p$ - bromobenzyl unit attached at the $\mathrm{C} 1$ position was the most potent $5-\mathrm{HT}_{2 \mathrm{~A}}$ ligand identified in this series. In fact compound 46 is the most potent $5-\mathrm{HT}_{2 \mathrm{~A}}$ aporphinoid antagonist known till date (Table 2).

Molecular modeling studies were used to identify key interactions of the $5-\mathrm{HT}_{2 \mathrm{~A}}$ receptor with the nantenine analogues [42]. Accordingly the protonated nitrogen atom and the oxygen atom in the methylenedioxy ring are involved in a hydrogen bond interaction with the Asp155 and Ser242 residues respectively. In addition, the alkyl side chain of the $\mathrm{C} 1$ alkyl analogues is buried in a hydrophobic pocket comprising of Phe234, Gly238, Leu228 and Ile341 side chains. This interaction seems to be critical for the observed enhanced affinity of the $\mathrm{C} 1$ alkyl analogues. Alternatively the moderate affinity of nantenine can be explained by the lack of this hydrophobic interaction.

At the $\mathrm{C} 2$ position the effect of small alkyl group substitution was studied [40]. Replacement with ethoxy $(\mathbf{4 7}, \mathrm{K}=378 \mathrm{nM})$ and propyloxy groups $\left(48, K_{e}=485 \mathrm{nM}\right)$ resulted in a moderate ( 2 and 1.7 times respectively) increase in potency. However replacements with larger alkoxy groups were detrimental for 5- $\mathrm{HT}_{2 \mathrm{~A}}$ receptor affinity (49, $\mathrm{K}=943 \mathrm{nM}$; and 33, $\mathrm{K}>10,000 \mathrm{nM}$ ). These substitutions also led to a decrease in affinity at the $\alpha_{1 \mathrm{~A}}$ receptor and a similar trend (decreased affinity with increase size of the alkyl substitution) was observed. Compound $52\left(\mathrm{~K}_{\mathrm{e}}=154 \mathrm{nM}\right)$ with a benzyloxy group at the $\mathrm{C} 2$ position was the most potent compound in this series. Overall a $\mathrm{C} 2$ group larger than propyl is not well tolerated for affinity at the $5-\mathrm{HT}_{2 \mathrm{~A}}$ receptor. A substitution at the $\mathrm{C} 2$ position is not absolutely required for affinity at the $5-\mathrm{HT}_{2 \mathrm{~A}}$ receptor as exemplified by compound 53 [43].

Replacement of the $N$-methyl group with other groups (compound 54 - 58) resulted in complete loss of affinity for the $5-\mathrm{HT}_{2 \mathrm{~A}}$ receptor, but affinity at the $\alpha_{1 \mathrm{~A}}$ receptor was retained. This suggested that the $\mathrm{N}$-Methyl group is important for affinity at the $5-\mathrm{HT}_{2 \mathrm{~A}}$ receptor. This trend is in contrast to the effect of similar $N$-substituted aporphine alkaloids at the $5-\mathrm{HT}_{1 \mathrm{~A}}$ and dopamine $\mathrm{D}_{1}$ and $\mathrm{D}_{2}$ receptors. Molecular docking studies indicate that the protonated nitrogen atom is involved in a hydrogen bond interaction with an Asp155 residue of the 5- $\mathrm{HT}_{2 \mathrm{~A}}$ receptor. The requirement of this salt bridge interaction was proven by evaluating the isochroman compounds $\mathbf{5 9}$ and $\mathbf{6 0}$ which were found to be completely inactive at the $5-\mathrm{HT}_{2 \mathrm{~A}}$ receptor [43]. 
It is also worth mentioning that both the $R$ and $S$ enantiomers of nantenine displayed antagonist effects at the $5-\mathrm{HT}_{2 \mathrm{~A}}$ receptor. This trend is in contrast to the effect of aporphine enantiomers at other receptor system including $5-\mathrm{HT}_{1 \mathrm{~A}}$ and dopamine $\mathrm{D}_{1}$ and $\mathrm{D}_{2}$, where enantiomers display opposing pharmacological effects as previously described. Furthermore in an in vivo rat assay, both the $R$ and $S$ enantiomers of nantenine completely blocked the effects of MDMA at a dose of $0.3 \mathrm{mg} / \mathrm{kg}$. This observation was found in concurrence by previous observations made by Indra et al. (Table 3).

Substitutions at the $\mathrm{C} 3$ position included the evaluation of a series of $\mathrm{C} 3$ halogenated compounds 62-66 [44]. In general halogenation is very well tolerated at the $\mathrm{C} 3$ position and all the halogenated nantenine analogues displayed enhanced 5-HT affinity. Compounds 62-64 showed doubling of $5-\mathrm{HT}_{2 \mathrm{~A}}$ antagonist potency (compared to their non-halogenated counterpart (61) irrespective of the halogen group present. Methylation of the $\mathrm{C} 2 \mathrm{OH}$ group resulted in further enhancement in the $5-\mathrm{HT}_{2 \mathrm{~A}}$ potency as seen by the $\mathrm{C} 3$ chloro (65) and $\mathrm{C} 3$ bromo (66) compounds respectively. This trend in enhancement of affinity following C3 halogenation has been reported in other aporphine compounds at the dopamine $\mathrm{D}_{1}$ and $\mathrm{D}_{2}$ receptors as well as for the $\alpha_{1}$ adrenergic receptor subtypes (i.e., $\alpha_{1 \mathrm{~A}}, \alpha_{1 \mathrm{~B}}$, and $\alpha_{1 \mathrm{D}}$ receptors) (32).

Modeling studies show the C3 halogenated compounds to have a completely different binding pose than the non-halogenated aporphines. In the case of the halogenated aporphines, the C3 halogen atom is oriented towards F339 and F340 residues, and it is this interaction that might be responsible for the higher affinity observed in this series of compounds. This lipophilic space can be further explored by suitable C3 hydrophobic substituents (Table 4).

\section{Aporphines as 5- $\mathrm{HT}_{2 \mathrm{~B}}$ Ligands}

Recently we reported a fortuitous discovery wherein a series of aporphine alkaloids having a $\mathrm{C} 4$ phenyl group were found to have affinity for the 5- $\mathrm{HT}_{2 \mathrm{~B}}$ receptor [45]. These compounds were initially designed to increase the 5- $\mathrm{HT}_{2 \mathrm{~A}}$ receptor affinity of nantenine; however to our surprise displayed no appreciable affinity for the $5-\mathrm{HT}_{2 \mathrm{~A}}$ receptor. This clearly indicated that a phenyl group at the $\mathrm{C} 4$ position of nantenine is detrimental for its 5 -HT receptor affinity. This in turn might be due to the inability of the $5-\mathrm{HT}_{2 \mathrm{~A}}$ binding cavity to accommodate the $\mathrm{C} 4$ phenyl group or due to a steric clash between a receptor side chain and the $\mathrm{C} 4$ phenyl group. Amongst this series, compound $\mathbf{6 7}$ had the highest affinity for the $5-\mathrm{HT}_{2 \mathrm{~B}}$ receptor $\left(\mathrm{K}_{\mathrm{i}}=96 \mathrm{nM}\right)$. When nantenine $\left(5-\mathrm{HT}_{2 \mathrm{~B}}\right.$, $\mathrm{K}=534 \mathrm{nM}$ ) is compared to compound 67 it is apparent that the $\mathrm{C} 4$ phenyl substituent positively impacts $5-\mathrm{HT}_{2 \mathrm{~B}}$ affinity and selectivity. Binding affinity of other analogues indicated a clear trend between the length of alkyl group at the $\mathrm{C} 1$ position and $5-\mathrm{HT}_{2 \mathrm{~B}}$ receptor affinity. Thus with increasing $\mathrm{C} 1$ alkyl chain length, the $5-\mathrm{HT}_{2 \mathrm{~B}}^{2 \mathrm{~B}}$ receptor affinity was found to decrease as evident from compound 67 to 71. A similar trend was also observed with respect to the size of the $N 6$ alkyl substituent in compounds 67,76 and 77 . Thus the larger the $N$-alkyl group the lower is the $5-\mathrm{HT}_{2 \mathrm{~B}}$ receptor affinity. Both the trends suggest that the binding pocket occupied by the $\mathrm{C} 1$ alkyl and N6 alkyl groups are small and do not accommodate larger substituents. The C1 cyclopropylmethyl analogue $\left(72, K_{i}=299 \mathrm{nM}\right)$ has similar affinity compared to the propyl analogue $(69, \mathrm{~K}=307 \mathrm{nM})$, which indicates that some degree of branching is tolerated. The allyl analogue (73, $\mathrm{K}=416 \mathrm{nM}$ ) had reduced affinity compared to its saturated analogue (69, $\mathrm{K}=307 \mathrm{nM})$ suggesting that saturation in this part of the alkyl chain is not tolerated. A phenolic $\mathrm{OH}$ group is not well tolerated for $5-\mathrm{HT}_{2 \mathrm{~B}}$ receptor affinity as indicated by $75\left(\mathrm{~K}_{\mathrm{i}}=715 \mathrm{nM}\right)$ (Table 5$)$.

Compound 67 has excellent selectivity for the $5-\mathrm{HT}_{2 \mathrm{~B}}$ receptor as it did not display any affinity across a broad range of other CNS receptors $\left(\alpha_{1 \mathrm{~A}}, \alpha_{1 \mathrm{~B}}, \alpha_{1 \mathrm{D}}, \beta_{1}, \beta_{2}, \beta_{3}, \mathrm{BZP}\right.$ rat brain site, $\mathrm{CB}_{2}, \mathrm{D}_{1}, \mathrm{D}_{2}, \mathrm{D}_{3}, \mathrm{D}_{4}$,

\begin{tabular}{|c|c|c|c|c|c|c|}
\hline \multirow[t]{2}{*}{ Compound } & \multirow[t]{2}{*}{$R_{1}$} & \multirow[t]{2}{*}{$\mathbf{R}_{2}$} & \multirow[t]{2}{*}{$\mathbf{R}_{3}$} & \multicolumn{2}{|c|}{$K_{e}(n M)$} & \multirow[t]{2}{*}{ Ref } \\
\hline & & & & $5-\mathrm{HT}_{2 \mathrm{~A}}$ & $\alpha_{1 \mathrm{~A}}$ & \\
\hline 47 & $\mathrm{Me}$ & Et & $\mathrm{Me}$ & 378 & 52 & [40] \\
\hline 48 & $\mathrm{Me}$ & $n-\operatorname{Pr}$ & $\mathrm{Me}$ & 389 & 133 & [40] \\
\hline 49 & $\mathrm{Me}$ & $n$-Bu & $\mathrm{Me}$ & 943 & 234 & [40] \\
\hline 50 & $\mathrm{Me}$ & $n$-Pen & $\mathrm{Me}$ & $>10000$ & 449 & [40] \\
\hline 51 & $\mathrm{Me}$ & CyclopropyIMe & $\mathrm{Me}$ & 484 & 195 & [40] \\
\hline 52 & $\mathrm{Me}$ & $\mathrm{Bn}$ & $\mathrm{Me}$ & 154 & 1917 & [40] \\
\hline 53 & Allyl & $\mathrm{H}$ & $\mathrm{Me}$ & 47 & 744 & [40] \\
\hline 54 & $\mathrm{Me}$ & $\mathrm{Me}$ & $N$-Et & $>10000$ & 26 & [40] \\
\hline 55 & $\mathrm{Me}$ & $\mathrm{Me}$ & $N-P r$ & $>10000$ & 38 & [40] \\
\hline 56 & $\mathrm{Me}$ & $\mathrm{Me}$ & $N-\mathrm{Bu}$ & $>10000$ & 210 & [40] \\
\hline 57 & $\mathrm{Me}$ & $\mathrm{Me}$ & $N-$ Pen & $>10000$ & 720 & [40] \\
\hline 58 & $\mathrm{Me}$ & $\mathrm{Me}$ & $\mathrm{N}$-CyclopropylMe & $>10000$ & 319 & [40] \\
\hline 59 & $\mathrm{Me}$ & $\mathrm{Me}$ & 0 & $>3000$ & $>3000$ & [43] \\
\hline 60 & Allyl & $\mathrm{Me}$ & 0 & $>3000$ & $>3000$ & [43] \\
\hline$(R)-29$ & $\mathrm{Me}$ & $\mathrm{Me}$ & $\mathrm{N}-\mathrm{Me}$ & 946 & 70 & [43] \\
\hline$(S)-29$ & $\mathrm{Me}$ & $\mathrm{Me}$ & $\mathrm{N}-\mathrm{Me}$ & 657 & 196 & [43] \\
\hline$( \pm)-29$ & $\mathrm{Me}$ & $\mathrm{Me}$ & $\mathrm{N}-\mathrm{Me}$ & 850 & 36 & [39] \\
\hline
\end{tabular}

Table 3: Binding affinity data of $\mathrm{C}-2$ and $\mathrm{N} 6$ nantenine analogues. 


\begin{tabular}{|c|c|c|c|c|}
\hline Compound & $\mathbf{R}_{1}$ & $x$ & & \\
\hline & & & $5-\mathrm{HT}_{2 \mathrm{~A}}$ & $\alpha_{1 \mathrm{~A}}$ \\
\hline 61 & $\mathrm{OH}$ & $\mathrm{H}$ & 282 & 255 \\
\hline 62 & $\mathrm{OH}$ & $\mathrm{Cl}$ & 130 & 1279 \\
\hline 63 & $\mathrm{OH}$ & $\mathrm{Br}$ & 126 & 68 \\
\hline 64 & $\mathrm{OH}$ & 1 & 133 & 60 \\
\hline 65 & $\mathrm{OMe}$ & $\mathrm{Cl}$ & 63 & 1273 \\
\hline 66 & $\mathrm{OMe}$ & $\mathrm{Br}$ & 48 & $>10000$ \\
\hline$( \pm)-29$ & $\mathrm{OMe}$ & $\mathrm{H}$ & 850 & 36 \\
\hline
\end{tabular}

Table 4: Binding affinity data of C-3 nantenine analogues.

\begin{tabular}{|c|c|c|c|}
\hline Compound & $\mathrm{R}_{1}$ & $\mathbf{R}_{2}$ & $5-\mathrm{HT}_{2 \mathrm{~A}}-\mathrm{K}_{\mathrm{e}}(\mathrm{nM})$ \\
\hline 67 & $\mathrm{Me}$ & $\mathrm{Me}$ & 96 \\
\hline 68 & $\mathrm{Et}$ & $\mathrm{Me}$ & 209 \\
\hline 69 & $n-\mathrm{Pr}$ & $\mathrm{Me}$ & 307 \\
\hline 70 & $n$-butyl & $\mathrm{Me}$ & 601 \\
\hline 71 & hexyl & $\mathrm{Me}$ & 663 \\
\hline 72 & CyclopropyIMe & $\mathrm{Me}$ & 299 \\
\hline 73 & allyl & $\mathrm{Me}$ & 416 \\
\hline 74 & p-bromobenzyl & $\mathrm{Me}$ & ND \\
\hline 75 & $\mathrm{H}$ & $\mathrm{Me}$ & 715 \\
\hline 76 & $\mathrm{Me}$ & $\mathrm{Et}$ & 419 \\
\hline 77 & $\mathrm{Me}$ & CyclopropylMe & 1429 \\
\hline$( \pm)-29$ & $\mathrm{OMe}$ & $\mathrm{Me}$ & 850 \\
\hline
\end{tabular}

Table 5: Binding affinity data of C-4 phenyl nantenine analogues

$\mathrm{D}_{5}$, DAT, DOR, GABA $, \mathrm{H}_{1}, \mathrm{H}_{2}, \mathrm{H}_{3}, \mathrm{H}_{4}, \mathrm{KOR}, \mathrm{M}_{2}, \mathrm{M}_{3}, \mathrm{M}_{4}, \mathrm{M}_{5}, \mathrm{MOR}$, NET, NMDA, SERT, sigma-1, sigma-2). 67 showed affinities for the following receptors other than $5-\mathrm{HT}_{2 \mathrm{~B}}: 5-\mathrm{HT}_{6}(627 \mathrm{nM}), \alpha_{2 \mathrm{a}}(719 \mathrm{nM})$, $\alpha_{2 B}(3220 \mathrm{nM}), \alpha_{2 \mathrm{C}}(433 \mathrm{nM}) \mathrm{M} 1\left(>10,000 \mathrm{nM}^{6}\right)$ and PBR $(2897 \mathrm{nM})$. In the 5- $\mathrm{HT}_{2 \mathrm{~B}}$ functional activity testing, 67 displayed antagonistic activity $\left(\mathrm{IC}_{50}=1 \mu \mathrm{M}\right)$. It is also of relevance that no $5-\mathrm{HT}_{2 \mathrm{~B}}$ agonist activity was found. To the best of our knowledge compound 67 is the first reported aporphine alkaloid to have selective affinity for the $5-\mathrm{HT}_{2 \mathrm{~B}}$ receptor and hence serves a valuable starting point for the design of potent 5- $\mathrm{HT}_{2 \mathrm{~B}}$ antagonist.

\section{Aporphines as 5- $\mathrm{HT}_{7}$ Ligands}

As mentioned previously, compound $\mathbf{1 4}$ was identified by Hedberg and co-workers as a potent 5- $\mathrm{HT}_{1 \mathrm{~A}}$ ligand. An expanded screening of $\mathbf{1 4}$ revealed it to have a decent affinity at the 5- $\mathrm{HT}_{7}$ receptor and accordingly a systematic structure activity relationship study was initiated [46]. Incorporation of symmetrically di-ortho-substituted C-11phenyl rings resulted in compounds (compound $\mathbf{7 8}$ and 79) with pronounced decrease in affinity at the $5-\mathrm{HT}_{7}$ receptor as well as $5-\mathrm{HT}_{1 \mathrm{~A}}$ and $\mathrm{D}_{2}$ receptors. These substitutions however resulted in increased selectivity for the $5-\mathrm{HT}_{7}$ receptor 


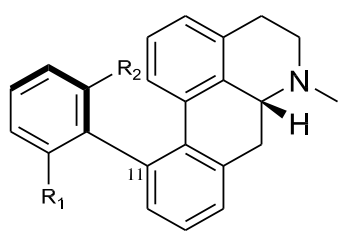

\begin{tabular}{|c|c|c|c|c|c|}
\hline \multirow[t]{2}{*}{ Compound } & \multirow[t]{2}{*}{$\mathbf{R}_{1}$} & \multirow[t]{2}{*}{$\mathbf{R}_{2}$} & \multicolumn{3}{|c|}{$K_{i}(n M)$} \\
\hline & & & $5-\mathrm{HT}_{7}$ & $5-\mathrm{HT}_{1 \mathrm{~A}}$ & $D_{2}$ \\
\hline 78 & $\mathrm{OH}$ & $\mathrm{OH}$ & 13 & 554 & 2030 \\
\hline 79 & OTf & OTf & 708 & $>10000$ & 2260 \\
\hline 80 & $\mathrm{Me}$ & $\mathrm{CN}$ & 20.80 & 778 & 2470 \\
\hline 81 & $\mathrm{CN}$ & $\mathrm{Me}$ & 3.79 & 142 & 498 \\
\hline 14 & $\mathrm{H}$ & $\mathrm{H}$ & 9.78 & 1.80 & 233 \\
\hline
\end{tabular}

Table 6: Binding affinity data of C-11 phenyl aporphine analogues.

\begin{tabular}{|c|c|c|c|c|c|}
\hline \multirow[t]{2}{*}{ Compound } & \multirow[t]{2}{*}{$\mathbf{R}_{1}$} & \multirow[t]{2}{*}{$\mathbf{R}_{2}$} & \multicolumn{3}{|c|}{$K_{i}(n M)$} \\
\hline & & & $5-\mathrm{HT}_{7}$ & $5-\mathrm{HT}_{1 \mathrm{~A}}$ & $\mathrm{D}_{2}$ \\
\hline 83 & $\mathrm{H}$ & $\mathrm{H}$ & 6.90 & 40.70 & 83.20 \\
\hline 84 & $\mathrm{OH}$ & $\mathrm{H}$ & 13.50 & 31 & 23.80 \\
\hline 85 & $\mathrm{H}$ & $\mathrm{OH}$ & 103 & 1210 & 215 \\
\hline 86 & $\mathrm{OH}$ & $\mathrm{Me}$ & 27.70 & 315 & 182 \\
\hline 87 & $\mathrm{Me}$ & $\mathrm{OH}$ & 4.30 & 61.50 & 26 \\
\hline 82 & - & - & 88 & 80 & 527 \\
\hline
\end{tabular}

Table 7: Binding affinity data of 1, 11 rigidified aporphine analogues

\begin{tabular}{|c|c|c|c|c|}
\hline Compound & $\mathbf{R}$ & \multicolumn{3}{|c|}{$K_{i}(n M)$} \\
\hline & & $5-\mathrm{HT}_{7}$ & $5-\mathrm{HT}_{1 \mathrm{~A}}$ & $5-\mathrm{HT}_{2 \mathrm{~A}}$ \\
\hline 88 & $\mathrm{H}$ & 20 & 314 & - \\
\hline 89 & $\mathrm{Me}$ & 43 & 171 & 966 \\
\hline 90 & $\mathrm{Et}$ & 69 & 506 & 818 \\
\hline 91 & $n$-butyl & 15 & 153 & 268 \\
\hline 92 & CyclopropylMe & 22 & 224 & 582 \\
\hline 93 & Allyl & 20 & 361 & 383 \\
\hline 94 & p-bromobenzyl & 54 & 102 & 418 \\
\hline
\end{tabular}

Table 8: Binding affinity data of C9 alkoxy aporphine analogues.

over $5-\mathrm{HT}_{1 \mathrm{~A}}$ receptor. A similar trend in selectivity was observed when unsymmetrical di-ortho-substituted C-11 phenyl rings were incorporated. Compound $\mathbf{8 0}$ in particular was the most potent compound identified in this series. Interestingly compound $\mathbf{8 1}$ (an atropisomer of compound $\mathbf{8 0}$ ) was 5 fold less potent than $\mathbf{8 0}$ (Figure 8).

Similarly SAR studies on the rigidified 1, 11 methyleneaporphine scaffold produced compounds having a diverse and interesting range of affinities at the 5-HT receptor [47]. When compared to compound 82, the rigidified methylene derivative $\mathbf{8 3}$ displayed 12 fold higher affinity at the $5-\mathrm{HT}_{7}$ receptor. This clearly indicated that the added strain of the rigidified methylene group was beneficial in increasing the $5-\mathrm{HT}_{7}$ receptor affinity. Introduction of substituents on the methylene carbon produced interesting pharmacological effects. For example, 
<smiles>CN1CCc2cccc3c2C1Cc1ccccc1-3</smiles>

Figure 8: Structure of 82

compound $84(6 \mathrm{a} R, 12 R$ - OH group above the plane) displayed higher affinity than compound $85(6 \mathrm{a} R, 12 S-\mathrm{OH}$ group below the plane). Adding a methyl group of $\mathrm{C}-12$ resulted in an opposite trend. Thus compound $87(6 \mathrm{a} R, 12 \mathrm{~S}-\mathrm{OH}$ group below the plane) displayed more affinity than compound $\mathbf{8 6}(6 \mathrm{a} R, 12 R-\mathrm{OH}$ group above the plane) (Tables 6 and 7).

In a more recent study, our group reported the evaluation of a series of C9 alkylated aporphine derivatives [48]. The design of these compounds was based on the structure of compound $\mathbf{8 8}$, which was previously reported to have $5-\mathrm{HT}_{1 \mathrm{~A}}$ and $5-\mathrm{HT}_{7}$ receptor affinity [49]. Most of these compounds displayed moderate to good affinity for the $5-\mathrm{HT}_{7}$ receptor with a moderate selectivity over the $5-\mathrm{HT}_{1 \mathrm{~A}}$ receptor. Overall it was found that a $\mathrm{C} 9$ phenolic $\mathrm{OH}$ group is not absolutely required for $5-\mathrm{HT}_{7}$ receptor affinity, and that small alkoxy groups are well tolerated at this position (Table 8).

\section{Conclusions}

Aporphine alkaloids have been studies in much detail over the past two decades mainly at the dopaminergic and $5-\mathrm{HT}_{1 \mathrm{~A}}$ receptor systems. Much of the recent work has focused on the evaluation of aporphine alkaloids as ligands at the $5-\mathrm{HT}_{24}$ and $5-\mathrm{HT}_{7}$ receptor system. This review concentrated on the SAR of aporphine alkaloids at the $5-\mathrm{HT}_{1 \mathrm{~A}}$, $5-\mathrm{HT}_{2 \mathrm{~A}}, 5-\mathrm{HT}_{2 \mathrm{~B}}$ and 5- $\mathrm{HT}_{7}$ receptor subtypes. At the $5-\mathrm{HT}_{1 \mathrm{~A}}$ receptor, various alkyl substitutions are tolerated at the $\mathrm{C}-10$ and $\mathrm{C}-11 \mathrm{~A}$ position, where a lipophilic pocket seems to interact with this substituents. Long chain alkyl substitutions at the $\mathrm{C} 1$ position were beneficial for affinity at the 5-HT receptor. Several rigidified aporphine alkaloids displayed enhanced affinity at the $5-\mathrm{HT}_{7}$ receptor. Although several analogues of aporphine alkaloids have been prepared and evaluated at these receptors, in general most of the SAR study has been limited to specific positions for particular receptor subtypes (for example C10 and C11 for $5-\mathrm{HT}_{1 \mathrm{~A}}$ and $5-\mathrm{HT}_{7}, \mathrm{C} 1$ and $\mathrm{C} 2$ for $5-\mathrm{HT}_{2 \mathrm{~A}}$ ). Considering the fact that small modifications on the aporphine scaffold produces diverse range of pharmacological actions, the unexplored chemical space around the aporphine template needs to be systematically evaluated. Furthermore, a truly selective aporphine alkaloid for either of these targets still needs to be discovered. Such a discovery will help medicinal chemist understand the often complex CNS receptor signaling process involved in the progression of several neuropsychiatric disorders and hence design better drugs targeting such disorders.

\section{References}

1. Zhang A, Zhang Y, Branfman AR, Baldessarini RJ, Neumeyer JL (2007) Advances in Development of Dopaminergic Aporphinoids. J. Med. Chem 50: 171-181.

2. Shamma M, Slusarchyk WA (1964) The Aporphine Alkaloids. Chem. Rev 64: 59-79.

3. Cabedo N, Berenguer I, Figadère B, Cortes D (2009) An overview on benzylisoquinoline derivatives with dopaminergic and serotonergic activities. Curr Med Chem 16: 2441-2467.

4. Zhang J, Xiong B, Zhen X, Zhang A (2009) Dopamine D1 receptor ligands: where are we now and where are we going. Med Res Rev 29: 272-294.
5. Faraone SV, Khan SA (2006) Candidate gene studies of attention-deficit/ hyperactivity disorder. J. Clin. Psychiat 67 Suppl 8: 13-20.

6. Kienast T, Heinz A (2006) Dopamine and the diseased brain. CNS Neurol Disord Drug Targets 5: 109-131.

7. RibariÄ S (2012) The pharmacological properties and therapeutic use of apomorphine. Molecules 17: 5289-5309.

8. Newman-Tancredi A, Kleven MS (2011) Comparative pharmacology of antipsychotics possessing combined dopamine D2 and serotonin 5-HT1A receptor properties. Psychopharmacology (Berl) 216: 451-473.

9. Nash JR, Sargent PA, Rabiner EA, Hood SD, Argyropoulos SV, et al. (2008) Serotonin 5-HT1A receptor binding in people with panic disorder: positron emission tomography study. Br J Psychiatry 193: 229-234.

10. Lesch KP, Wiesmann M, Hoh A, Müller T, Disselkamp-Tietze J, et al. (1992) 5-HT1A receptor-effector system responsivity in panic disorder. Psychopharmacology (Berl) 106: 111-117.

11. Savitz J, Lucki I, Drevets WC (2009) 5-HT(1A) receptor function in major depressive disorder. Prog Neurobiol 88: 17-31.

12. Marek GJ, Carpenter LL, McDougle CJ, Price LH (2003) Synergistic Action of 5-HT2A Antagonists and Selective Serotonin Reuptake Inhibitors in Neuropsychiatric Disorders. Neuropsychopharmacol 28: 402-412.

13. Celada P, Puig M, Amargós-Bosch M, Adell A, Artigas F (2004) The therapeutic role of 5-HT1A and 5-HT2A receptors in depression. J Psychiatry Neurosci 29: 252-265.

14. Mnie-Filali $\mathrm{O}$, Faure $\mathrm{C}$, Lambás-Señas $\mathrm{L}$, El Mansari $\mathrm{M}$, Belblidia $\mathrm{H}$, et al. (2011) Pharmacological blockade of 5-HT7 receptors as a putative fast acting antidepressant strategy. Neuropsychopharmacology 36: 1275-1288.

15. Hedlund PB (2009) The 5-HT7 receptor and disorders of the nervous system an overview. Psychopharmacology (Berl) 206: 345-354.

16. Lopez-Rodriguez ML, Benhamu B, Morcillo MJ, Porras E, Lavandera JL, et al. (2004) Serotonin 5-HT7 Receptor Antagonists. Current Medicinal Chemistry Central Nervous System Agents 4: 203-214.

17. Cingolani GM, Di Stefano A, Napolitani F, Mosciatti B, Giorgioni G, et al. (2001) Synthesis and preliminary pharmacological evaluation of 5-hydroxyand $\quad 5,6$-dihydroxy-1,2,3,7,12,12a-hexahydrobenzo[5,6]cyclohepta[1,2,3-ij] isoquinoline derivatives as dopamine receptor ligands. Bioorg Med Chem 9 : $1447-1458$.

18. Yang Z, Song Z, Xue W, Sheng J, Shu Z, et al. (2014) Synthesis and structureactivity relationship of nuciferine derivatives as potential acetylcholinesterase inhibitors. Med Chem Res 23: 3178-3186.

19. Jung HA, Min BS, Yokozawa T, Lee JH, Kim YS, et al. (2009) Anti-Alzheimer and antioxidant activities of Coptidis Rhizoma alkaloids. Biol Pharm Bull 32 1433-1438.

20. Ivorra MD, Valiente M, Martínez S, Madrero Y, Noguera MA, et al. (2005) 8-NH2-boldine, an antagonist of alpha1 A and alpha1B adrenoceptors without affinity for the alpha1D subtype: structural requirements for aporphines at alpha1-adrenoceptor subtypes. Planta Med 71: 897-903.

21. Chaudhari VM, Patel MS, Patel (2013) Microemulsion Based Gel: A Review. Int. J. Univers. Pharm. Bio Sci 3: 63-78

22. Cannon JG, Mohan P, Bojarski J, Long JP, Bhatnagar RK, et al. (1988) (R)-(-)10-methyl-11-hydroxyaporphine: a highly selective serotonergic agonist. J Med Chem 31: 313-318.

23. Cannon JG, Moe ST, Long JP (1991) Enantiomers of 11-hydroxy-10methylaporphine having opposing pharmacological effects at $5-\mathrm{HT} 1 \mathrm{~A}$ receptors. Chirality 3: 19-23.

24. Gao Y, Zong R, Campbell A, Kula NS, Baldessarini RJ, et al. (1988) Synthesis and dopamine agonist and antagonist effects of $(R)-(-)$ - and $(S)-(+)-11$-hydroxyN-n-propylnoraporphine. J Med Chem 31: 1392-1396.

25. Cannon JG, Raghupathi R, Moe ST, Johnson AK, Long JP (1993) Preparation and pharmacological evaluation of enantiomers of certain nonoxygenated aporphines: (+)- and (-)-aporphine and (+)- and (-)-10-methylaporphine. J. Med. Chem 36: 1316-1318.

26. Cannon JG, Flaherty PT, Ozkutlu U, Long JP (1995) Structure-Activity Relationship of .alpha.-Galactosylceramides against B16-Bearing Mice. J Med. Chem 38: 2176-2187. 
27. Si YG, Gardner MP, Tarazi FI, Baldessarini RJ, Neumeyer JL (2007) R-(-)-Nalkyl-11-hydroxy-10-hydroxymethyl- and 10-methyl-aporphines as 5-HT1A receptor ligands. Bioorg Med Chem Lett 17: 4128-4130.

28. Hedberg MH, Johansson AM, Nordvall G, Yliniemelä A, Li HB, et al. (1995) (R)11-hydroxy- and (R)-11-hydroxy-10-methylaporphine: synthesis, pharmacology, and modeling of D2A and 5-HT1A receptor interactions. J Med Chem 38: 647 658

29. Hedberg MH, Linnanen T, Jansen JM, Nordvall G, Hjorth S, et al. (1996) 11-substituted (R)-aporphines: synthesis, pharmacology, and modeling of D2A and 5-HT1A receptor interactions. J Med Chem 39: 3503-3513.

30. Liu Z, Zhang H, Ye N, Zhang J, Wu Q, et al. (2010) Synthesis of dihydrofuroaporphine derivatives: identification of a potent and selective serotonin 5-HT 1A receptor agonist. J Med Chem 53: 1319-1328.

31. Zhang H, Ye N, Zhou S, Guo L, Zheng L, et al. (2011) Identification of $\mathrm{N}$-propylnoraporphin-11-yl 5-(1,2-dithiolan-3-yl)pentanoate as a new antiParkinson's agent possessing a dopamine D2 and serotonin 5-HT1A dualagonist profile. J Med Chem 54: 4324-4338.

32. Liu Z, Chen X, Yu L, Zhen X, Zhang A (2008) Synthesis and pharmacological investigation of novel 2-aminothiazole-privileged aporphines. Bioorg Med Chem 16: 6675-6681.

33. Shoji N, Umeyama A, Takemoto T, Ohizumi Y (1984) Serotonergic receptor antagonist from Nandina domestica thunberg. J. Pharm. Sci. 73: 568-570.

34. Indra B, Tadano T, Nakagawasai O, Arai Y, Yasuhara H, et al. (2002) Suppressive effect of nantenine, isolated from Nandina domestica Thunberg, on the 5-hydroxy-L-tryptophan plus clorgyline-induced head-twitch response in mice. Life Sci 70: 2647-2656.

35. Indra B, Matsunaga K, Hoshino O, Suzuki M, Ogasawara H, et al. (2002) Structure-activity relationship on (+/-)-nantenine derivatives in antiserotonergic activities in rat aorta. Can J Physiol Pharmacol 80: 198-204.

36. Indra B, Matsunaga K, Hoshino O, Suzuki M, Ogasawara H, et al. (2002) Structure-activity relationship studies with (+/-)-nantenine derivatives for alpha1-adrenoceptor antagonist activity. Eur J Pharmacol 437: 173-178.

37. Fantegrossi WE, Kiessel CL, Leach PT, Van Martin C, Karabenick RL, et al. (2004) Nantenine: an antagonist of the behavioral and physiological effects of MDMA in mice. Psychopharmacology (Berl) 173: 270-277.

38. Legendre O, Pecic S, Chaudhary S, Zimmerman SM, Fantegrossi WE, et al. (2010) Synthetic studies and pharmacological evaluations on the MDMA ('Ecstasy') antagonist nantenine. Bioorg Med Chem Lett 20: 628-631.

39. Chaudhary S, Pecic S, Legendre O, Navarro HA, Harding WW (2009) $(+/-)-$ Nantenine analogs as antagonists at human $5-\mathrm{HT}(2 \mathrm{~A})$ receptors: $\mathrm{C} 1$ and flexible congeners. Bioorg Med Chem Lett 19: 2530-2532.

40. Chaudhary S, Ponnala S, Legendre O, Gonzales JA, Navarro HA, et al. (2011) New aporphinoid 5-HT2A and $\hat{I} \pm 1 A$ antagonists via structural manipulations of nantenine. Bioorg Med Chem 19: 5861-5868.

41. Ponnala S, Kapadia N, Madapa S, Alberts IL, Harding WW (2015) Synthesis and evaluation of aporphine analogs containing $\mathrm{C} 1$ allyl isosteres at the h5HT(2A) receptor. Bioorg Med Chem Lett 25: 5102-5106.

42. Pecic S, Makkar P, Chaudhary S, Reddy BV, Navarro HA, et al. (2010) Affinity of aporphines for the human $5-\mathrm{HT} 2 \mathrm{~A}$ receptor: insights from homology modeling and molecular docking studies. Bioorg Med Chem 18: 5562-5575.

43. Ponnala S, Gonzales J, Kapadia N, Navarro HA, Harding WW (2014) Evaluation of structural effects on $5-\mathrm{HT}(2 \mathrm{~A})$ receptor antagonism by aporphines: identification of a new aporphine with 5-HT(2A) antagonist activity. Bioorg Med Chem Lett 24: 1664-1667.

44. Ponnala S, Kapadia N, Navarro HA, Harding WW (2014) Aporphinoid antagonists of 5-HT2A receptors: further evaluation of ring A substituents and the size of ring C. Chem Biol Drug Des 84: 558-566.

45. Kapadia N, Harding WW (2015) C4 phenyl aporphines with selective h5HT(2B) receptor affinity. Bioorg Med Chem Lett 25: 3451-3454.

46. Linnanen T, Brisander M, Unelius L, Rosqvist S, Nordvall G, et al. (2001) Atropisomeric Derivatives of 2',6'-Disubstituted (R)-11-Phenylaporphine: Selective Serotonin 5-HT7 Receptor Antagonists. J. Med. Chem. 44: 1337 1340.

47. Linnanen T, Brisander M, Unelius L, Sundholm G, Hacksell U, et al. (2000) Derivatives of (R)-1,11-Methyleneaporphine: Synthesis, Structure, and Interactions with G-Protein Coupled Receptors. J. Med. Chem. 43: 1339-1349.

48. Madapa S, Harding WW (2015) Semisynthetic Studies on and Biological Evaluation of N-Methyllaurotetanine Analogues as Ligands for 5-HT Receptors. J Nat Prod 78: 722-729.

49. Gafner S, Dietz BM, McPhail KL, Scott IM, Glinski JA, et al. (2006) Alkaloids from Eschscholzia californica and their capacity to inhibit binding of $[3 \mathrm{H}] 8$ Hydroxy-2-(di-N-propylamino)tetralin to 5-HT1A receptors in Vitro. J Nat Prod 69: 432-435. 